区別し，放射線防護上の整理をしています。

内部被ばくは放射性物質が体内に取り达まれることに よって起こります。日常の生活の中で内部被ばくが起こ るのは，空気や水や食べ物に放射性物質が混ざり，私た ちがそれらを，呼吸や食事などで摂取した場合です。こ れらの経路を通じて体内に取り达まれた放射性物質は血 液またはリンパ液とともに体内を移動します。体内の臓 器や組織はそれぞれ特定の種類の放射性物質を沈着させ やすい性質を持っています。例えば，ヨウ素 ${ }^{(131} \mathrm{I}$ など) は甲状腺に集まることが知られています。

放射性物質からの放射線は沈着臓器・組織とその周辺 の臓器・組織を照射し, その結果として内部被ばくが発 生します。放射性物質のうち，ヨウ素 $\left({ }^{131} \mathrm{I}\right.$ など)のよう に特定の臓器・組織に沈着するものは身体の一部に被ば くをもたらしますが(部分被ばく)，トリチウム，カリウ 厶 $\left({ }^{40} \mathrm{~K}\right)$ ，セシウム $\left({ }^{137} \mathrm{Cs}\right)$ などは身体全体に分布するの で全身が放射線の照射を受けることになります(全身均 等被ばく)。

身体内の放射性物質の量は，その放射性物質の放射性 核種による固有の半減期 (物理学的半減期 $T_{\mathrm{p}}$ ) と身体の 代謝による半減期 (生物学的半減期 $T_{\mathrm{b}}$ ) とで決まる割合 (実効半減期 ; 有効半減期ともいう) で減少していきま す。例えば， ${ }^{137} \mathrm{Cs}$ の物理的半減期は 30.07 年ですが，体 内に取り込まれた ${ }^{137} \mathrm{Cs}$ が体外へ排出される速度をあら わす生物学的半減期は110日 (ICRP Pub. 78)です。その 放射性物質に，身体がどのくらいの期間曝されるか(実 効半減期 $\left.T_{\text {eff }}\right)$ は, この 2 つの半減期で決まります。 $2 つ$ の半減期の逆数の和が, その核種の実効半減期の逆数に なっているからです。

$1 / T_{\text {eff }}=1 / T_{\mathrm{p}}+1 / T_{\mathrm{b}}$

各臓器・組織への放射性物質の沈着量, 沈着した放射
性物質が放つ放射線の種類, 臓器・組織に与えるエネル ギー, 実際に沈着している期間の長さ (実効半減期)など に基づいて，内部被ばくの大きさ(内部被ばく線量)が計 算できます。内部被ばく線量の評価には，「実効線量係 数 $(\mathrm{Sv} / \mathrm{Bq}) 」 か ゙$ 用いられます。これは， $1 \mathrm{~Bq}$ を摂取した 人がその放射性物質でその後内部被ばくし続けた時の合 計線量(預託実効線量といいます)を表しています。この 内部被ばくの線量評価のための積分期間は，作業者や成 人の一般公衆で 50 年，子どもでは摂取した年齢から70歳 までとされています。この計算方法により，体内に取り 込まれた放射性物質による，その後の体内に残留する期 間までも考慮に入れた総線量をまとめて評価できること になります。実効線量係数は http : //www.remnet.jp/ lecture/b 05_01/4_1.html などで調べることができま す。

内部被ばくは外部被ばくに比べて，測定したり，線量 を評価したりすることは簡単ではありませんが，不要な 放射性物質を体内に取り込まない工夫をする(たとえば 粒子性の放射性物質の場合はマスクや夕オルで口を覆う など)ことである程度避けることもできます。外部被ば くも, 内部被ばくも, 受けた実効線量 $(\mathrm{Sv})$ の值が同じ であれば, 身体に対する影響は同じです。単位であるシー ベルトや実効線量については, http://www.radi-edu.jp /pages/columns/11などが参考になります。

《引用文献 (一部修正) · 参考文献》

$\lceil$ ATOMICA」http ://www.rist.or.jp/atomica/ 「緊急被ばく医療研修のホームページ」

http : //www.remnet.jp/

「やさしい放射線とアイソトープ」日本アイソトープ協会編

「らでい」http://www.radi-edu.jp/pages/columns/11

\title{
FOCUS 遠隔地被ばくについて
}

東電福島第一原子力発電所の事故により，原子炉内に 閉じ达められていた放射性物質が大気に放出され，各地 での空間線量率 $(\mathrm{mGy} / \mathrm{h}, \mu \mathrm{Gy} / \mathrm{h})$ の計測結果等が公表 されています。今回の事故で放出されている放射性核種 は，原子炉の運転中に発生した核分裂反応によって生成 したものです。また，現地では原子炉内での連鎖的な核 分裂反応を終了させており，核分裂反応を制御できな かったチェルノブイリ事故や JCO の臨界事故とは異な り, 多量の中性子線の放出などは確認されておりませ ん。

新聞やテレビ報道，インターネット配信などでは，各 地のモニタリングポストでの線量当量率 $(\mathrm{mSv} / \mathrm{h}, \mu \mathrm{Sv} /$ h)の測定結果やヨウ素-131, セシウム-134, 137といっ た放射性同位元素の名称が見受けられます。ヨウ素(I)
は，ハロゲン元素の一つであり，高温で気体になりやす い性質を持つため，原子力発電所の事故などでは放出さ れやすい元素の一つとして挙げられます。また，セシウ ム $(\mathrm{Cs})$ はアルカリ金属元素の一つで水に溶けやすい性 質を持つため，燃料棒の破損などの事象が生じると冷却 水中に溶出しやすく，ミストなどで放出されやすい元素 と考えられます。

これらの放射性同位元素からの被ばくについては，大 きくは外部被ばくと内部被ばくに分類することができま す。外部被ばくは，体外に存在する放射性同位元素から の放射線による被ばくのことをいい，内部被ばくは，呼 吸や飲食により体内に取り込まれた放射性同位元素から の放射線による被ばくのことをいいます。今回話題と なっているヨウ素もセシウムも，化学的に水に溶けやす 
い性質があり，外部被ばくとなる皮膚や衣服などに付着 しても，水洗により容易に除去(除染)することが可能で す。

一方，内部被ばくは放射性同位元素が体内に取り込ま れてしまうため, 体内に長期間留まる場合, 長期にわたっ て被ばくを受ける可能性があります。

一方, 体内に取り込まれた物質は,その特性に応じて， 体内組織に分布した後に代謝や排泄により体外へと放出 されます。これまでに飛来が確認されているヨウ素は， 摂取量の $70 \%$ は吸収されることなく排出され，残りの30 \%が主に甲状腺に集積します。同じく飛来が確認されて いるセシウムは, ほぼ全量が吸収されて全身の筋肉に分 布します。

これらの放射性物質は有効半減期に従い, 減少してい き，被ばくの影響も低減していきます。とはいえ，放射 性物質の体内取り达みはできるだけ低減することが望ま しく，湿ったマスクの着用，手洗い，外出時はできるだ け皮膚を直接露出しない，などの予防措置を講じること が重要と考えられます。

遠隔地被ばくは飛来したヨウ素やセシウムによる被ば くですが, 飛来の過程で拡散希釈されるためその量 (濃 度)は距離とともに急激に減少します。また，風向きに よっても影響を受け，雨が降れば雨水に溶け込んで落ち てきます。しかし，原子炉の近隣での直接被ばくのよう に，体の外部から皮膚を通して臓器が損傷することはあ りません。先に述べた予防措置によって内部被ばくを極 力防止することが重要です。
空間線量率： 対象とする空間の 1 時間あたりの放射 線量。線量率の単位は, $\mathrm{Gy} / \mathrm{h}$ (グレイ/時)で表します。 空気吸収線量率ともいいます。単位は $\mathrm{mGy} / \mathrm{h}$ (ミリグレ イ/時：1時間当たりに吸収したエネルギー)， $\mu \mathrm{Gy} /$ 時 (マイクロ/時), $\mathrm{mGy} / \mathrm{h}$ (ミリグレイ/時 $)=1,000 \mu \mathrm{Gy} / \mathrm{h}$ (マイクログレイ/時)。

線量当量率：吸収線量に放射線の種類ごとに定めら れた放射線荷重係数を乗じた量 (線量当量)の 1 時間当た りの量。単位は $\mathrm{mSv} / \mathrm{h}$ (ミリシーベルト/時：1時間当 たりの生体への被ばくの大きさ)， $\mu \mathrm{Sv} / \mathrm{h}$ (マイクロシー ベルト/時), $\mathrm{mSv} / \mathrm{h}$ (ミリシーベルト/時 $)=1,000 \mu \mathrm{Sv} /$ $\mathrm{h}$ (マイクロシーベルト/時)。

吸収線量： 放射線が物質に照射されたときに物質が 吸収するエネルギーの, 単位質量あたりの量。単位は $\mathrm{Gy}$ (グレイ), $\mathrm{mGy}$ (ミリグレイ), $\mu \mathrm{Gy}$ (マイクログレイ)。 $1(\mathrm{~Gy})$ グレイ $=1,000(\mathrm{mGy})$ ミリグレイ, $1(\mathrm{mGy})$ ミリ グレイ $=1,000(\mu \mathrm{Gy})$ マイクログレイ。

放射性同位元素： 同じ元素で中性子の数が違う核種 の関係を同位元素と呼びます。同位元素には安定なもの と不安定なものがあり，不安定なものは時間とともに放 射線を発生し，安定なのものに変わります。この不安定 なものが放射性同位元素です。

有効半減期： 体内に取り込まれた放射性物質からの 放射能が，それ自身の減衰や人体の代謝・排泄により半 分になるまで減少するまでに要する時間をいう。実効半 減期ともいう。

*「アイソトープ便覧改訂 3 版」および「アイソトープ手帳 10 版」による。5.1日という説もある。

\section{FOCUS 食と住居について}

今回の福島原子力発電所の事故では，原子炉や使用済 燃料プールから放射性物質が放出され周辺環境に広がっ てしまいました。

これに伴い，国の暫定基準を超える放射性物質により 污染された野菜が見つかりましたが，基準を超えて污染 された食物は市場に出回らないので心配ありません。基 準值は, そのレベルに污染された食品を 1 年間食べ続け ても健康影響が出る心配のない量に設定されています。 したがって，仮に基準值を超える食品を口にしても，直 ちに影響がでるような恐れは全くありません。当然のこ とながら，国の暫定基準*未満の野菜等を食べても何の 問題もありません。不安であれば，きれいな水でよく洗 えば安心でしょう。

さらに，避難地域，屋内退避地域に置いてあった食べ 物でも密閉容器に入っている食べ物, 冷蔵庫などに貯蔵
されていた食べ物は放射性物質によって污染されている 恐れは全くありません。

なお，これまでに起こった海外の原子力事故の例で は，原子力発電所からの放射性物質の放出が止まった後 に，家屋の屋根，庭，道路，土壤の放射性物質の濃度を 測定して，ある基準を超えるような污染が残っている場 合には，必要に応じて洗浄などにより污染が取り除かれ るなど，その場所で生活しても健康に影響がないレベル になれば元の住居に戻って暮らすことが可能になってい ます。今回の事故の場合については，今後，国で方針が 検討されます。

*食安発0317第 3 号

http : //www.mhlw.go.jp/stf/houdou/2 r 9852000001558 eimg/2 r 9852000001559 v.pdf 原子力安全委員会により示された指標值。 